\title{
Evaluation of Stability and In Vitro Security of Nanoemulsions Containing Eucalyptus globulus Oil
}

\author{
Samantha Nunes de Godoi, ${ }^{1,2}$ Priscilla Maciel Quatrin, ${ }^{2}$ \\ Michele Rorato Sagrillo, ${ }^{1,2}$ Kátia Nascimento, ${ }^{3}$ Roger Wagner, ${ }^{4}$ Bruna Klein, ${ }^{4}$ \\ Roberto Christ Vianna Santos, ${ }^{2,5}$ and Aline Ferreira Ourique ${ }^{1,2}$ \\ ${ }^{1}$ Curso de Biomedicina, Centro Universitário Franciscano, Santa Maria, RS, Brazil \\ ${ }^{2}$ Programa de Pós-Graduação em Nanociências, Centro Universitário Franciscano, Santa Maria, RS, Brazil \\ ${ }^{3}$ Laboratório Escola de Análises Clínicas, Centro Universitário Franciscano, Santa Maria, RS, Brazil \\ ${ }^{4}$ Departamento de Tecnologia e Ciência dos Alimentos, Universidade Federal de Santa Maria, Santa Maria, RS, Brazil \\ ${ }^{5}$ Departamento de Microbiologia e Parasitologia, Universidade Federal de Santa Maria, Santa Maria, RS, Brazil \\ Correspondence should be addressed to Aline Ferreira Ourique; alineourique@gmail.com
}

Received 29 December 2016; Accepted 14 May 2017; Published 11 June 2017

Academic Editor: Maqusood Ahamed

Copyright (c) 2017 Samantha Nunes de Godoi et al. This is an open access article distributed under the Creative Commons Attribution License, which permits unrestricted use, distribution, and reproduction in any medium, provided the original work is properly cited.

\begin{abstract}
Essential oil of Eucalyptus globulus presents several pharmacological properties. However, their therapeutic efficacy may be affected by limitations due to several conditions, rendering it difficult to obtain stable and effective pharmaceutical formulations. The use of nanotechnology is an alternative to improve their characteristics aiming to ensure their stability and effectiveness. Furthermore, studies about the possible toxic effects of nanostructures are necessary to evaluate safety when the formulation comes into contact with human cells. Hence, in this paper, we evaluate for the first time the stability and in vitro cytogenotoxicity of nanoemulsions containing Eucalyptus globulus in peripheral blood mononuclear cells. As a result, the stability study found that the best condition for storage up to 90 days was refrigeration $\left(4^{\circ} \mathrm{C}\right)$; it was the condition that best preserved the nanometric features. The content of the major compounds of oil was maintained after nanoencapsulation and preserved over time. In tests to evaluate the safety of this formulation, we can conclude that, at a low concentration (approximately 0.1\%), Eucalyptus globulus nanoemulsion did not cause toxicity in peripheral blood mononuclear cells and also showed a protective effect in cells against possible damage when compared to oil in free form.
\end{abstract}

\section{Introduction}

According to the World Health Organization (WHO), a large part of the global population makes use of some type of plant to treat or improve the symptoms of pathological processes [1]. In addition, the use of natural medicine has gained prominence due to the absence of side effects [2].

Essential oils are natural compounds known for their medicinal properties and their use in the perfumery industry. In the environment, the essential oils have the function of protecting the plants against injuries caused by microorganisms [3]. Essential oils are products from plants, which has the vital function of causing a better adaptation of the plant in the environment where it is found; in addition, these oils can be obtained through several parts of these plants [4]. Currently, $10 \%$ of essential oils studied are used for industrial purposes, although thousands of species of essential oils are known [5].

In Brazil, the main species producing medicinal oil is Eucalyptus globulus [6]. Eucalyptus is a medicinal plant belonging to the Myrtle family [7], and although it is already a widely used species, all its medicinal benefits are not yet known; so it is important to study an essential oil from eucalyptus, Eucalyptus globulus, to better understand its pharmacological properties and possible disadvantages arising from its use $[8,9]$.

Among the disadvantages of this oil are susceptibility to volatilization, low aqueous solubility, and instability against the presence of oxygen and light, and in addition to impairing 
its therapeutic action, the production of effective formulations is disrupted [10].

A possibility of increasing the stability and efficacy of these compounds would be nanoencapsulation [11]. In the field of medicinal plants, the application of nanotechnology presents benefits such as increased apparent solubility, bioavailability, biocompatibility, and protection against physical and chemical degradation of the active principle, thereby inducing an increase in the pharmacological action and protection against toxicity [12]. Among the nanosystems, nanoemulsions are the best when used as carriers of essential oils, or their compounds, due to their high affinity provided in the formation of droplets, enhancing the internalization in biological membranes easily [13]. Nanoemulsions are stable oil droplets with an average size smaller than $100 \mathrm{~nm}$ formed by two immiscible phases stabilized by a surfactant. They may be obtained by different methods, depending on the desired structure and intended functionality [14]. Nanoemulsions have a transparent or translucent appearance and demonstrate greater stability when compared to conventional emulsions [15]. High energy to promote a shear rate is required; usually it is achieved through high-pressure homogenizers or ultrasonic generators [16]. The use of this type of nanosystem can increase the concentration of bioactive compounds in specific places of living organisms [17].

This nanosystem has been widely used in association with essential oils for the most diverse applications. Gomes et al. [18] showed the cytotoxic activity against tumor cell lines of two essential oils (Drimys angustifolia Miers and D. brasiliensis Miers) in nanoemulsions; Duarte et al. [19] evaluated the larvicidal activity of a nanoemulsion containing Rosmarinus officinalis essential oil against Aedes aegypti; and Lu et al. [17] proposed the use of citral nanoemulsions to improve the physicochemical stability of the compound in addition to enhancing its antimicrobial action.

It is possible to verify that nanoemulsions are systems widely used in association with essential oils for several areas, to improve the physical-chemical stability of the essential oil but also to maximize the action of this oil.

The production of nanoemulsions of Eucalyptus (E. globulus) has been reported in a few studies in the literature [20,21]. These authors used concentrations of $6 \%$ and $10 \%$ of essential oil and successfully obtained the formulation containing this oil by ultrasonication technique.

As important as ensuring the efficacy of the formulation is to ascertain its safety; thus, the cell culture and tissue have been widely used for toxicity testing. These tests produce prior knowledge about the cytotoxicity of the substance when it comes into contact with the cells of living beings [22].

Therefore, this study aimed to prepare and characterize nanoemulsions containing $5 \%$ of E. globulus oil, to determine the best conditions for their storage and to evaluate the safety of these formulations while being in contact with healthy human cells (peripheral blood mononuclear cells).

\section{Materials and Methods}

2.1. Materials and Reagents. E. globulus oil was supplied by Ferquima (São Paulo, Brazil). Sorbitan monooleate (Span
$80^{\circledR}$ ) was supplied by Sigma-Aldrich (São Paulo, Brazil). Polysorbate 80 (Tween $80^{\circledR}$ ) was supplied by LabSynth ${ }^{\circledR}$ (São Paulo, Brazil). Caprylic/capric triglyceride mixture was acquired from Alpha Química Ltda. (Porto Alegre, Brazil). Histopaque was supplied by Sigma-Aldrich (São Paulo, Brazil). Fetal Bovine Serum, RPMI 1640, and Penicillin/ Streptomycin were supplied by Cultilab (São Paulo, Brazil). Dimethyl sulfoxide (DMSO) and trypan blue were supplied by Nuclear (São Paulo, Brazil).

2.2. Preparation of E. globulus Nanoemulsions. The nanoemulsions were prepared using the emulsification method under high agitation employing Ultra-Turrax ${ }^{\circledR}$ equipment with cooling. No organic solvent or rotary evaporator stage was used to prevent evaporation of volatile oil compound. The oil phase of the nanoemulsion consists of E. globulus oil (5\%) and sorbitan monooleate (2\%), while the aqueous phase comprises polysorbate $80(2 \%)$ and ultrapure water. Both phases were previously solubilized with the aid of a magnetic stirrer, and then the oil phase was injected into the aqueous phase under agitation of $10,000 \mathrm{rpm}$. After the injection, the stirring was increased to $17,000 \mathrm{rpm}$ and maintained for 1 hour. Blank nanoemulsions containing capric or caprylic acid triglyceride in place of E. globulus were also prepared in the same mode for comparative purposes. All formulations were produced in triplicate.

\subsection{Characterization of the Essential Oil and Nanoemulsion} Oil Content. The essential oil of E. globulus was characterized according to Amini et al. [23] with modifications in a Varian gas chromatograph, model Star 3400CX (CA, USA) equipped with a flame ionization detector (GC-FID). An aliquot of $1 \mu \mathrm{L}$ of the solutions was injected using a Varian autosampler model 8200 (CA, USA) in the chromatograph injection port under $250^{\circ} \mathrm{C}$ in split mode $(1: 20)$. The compounds were separated on a nonpolar capillary column of fused silica BPX $5(25 \mathrm{~m} \times 0.22 \mathrm{~mm} \times 0.25 \mu \mathrm{m})$ (SGE, Australia). Hydrogen was used as carrier gas at a constant pressure of 20 psi. The initial column temperature was adjusted at $40^{\circ} \mathrm{C}$ and held for 1 minute. Then, temperature increased at $1^{\circ} \mathrm{C} \mathrm{min}^{-1}$ to $70^{\circ} \mathrm{C}$ and then to $220^{\circ} \mathrm{C}$ at $10^{\circ} \mathrm{C} \mathrm{min}^{-1}$ and was kept under isothermal conditions for 3 minutes. The detector temperature was maintained at $250^{\circ} \mathrm{C}$. A series of n-alkane homologues were analyzed under the same chromatographic conditions to calculate the linear retention index (LRI).

The qualitative analysis of the compounds was performed by a Shimadzu QP2010 Plus gas chromatograph coupled to a mass spectrometer (GC/MS, Shimadzu Corporation, Kyoto, Japan). For this analysis, the same chromatographic conditions described above were used and helium was used as the carrier gas. The detector was operated in electron impact ionization mode with $70 \mathrm{eV}$ ionization energy and a mass scan range of $35-350 \mathrm{~m} / z$. Analytes were identified based on comparison to the mass spectra in the library available at the National Institute of Standards and Technology (NIST) comparing the calculated linear retention indices with those available in the scientific literature. The percent relative amount of each identified compound was obtained from the peak area found using the FID. 
The E. globulus oil had to be extracted from the nanoemulsions to analyze the oil content. For this, $100 \mu \mathrm{L}$ of the suspension was placed in microvial tubes and subjected to $50^{\circ} \mathrm{C}$ for 15 minutes in a dry block heating TE-O21 (Tecnal, Brazil). Then $1 \mathrm{~mL}$ of acetonitrile was added and the solution subjected to vortexing for 1 minute. Subsequently, the solution was centrifuged for 5 minutes at 10,000 rpm. Compared to pure commercial oil, used for the production of nanoemulsions, $5 \mu \mathrm{L}$ diluted in $1 \mathrm{~mL}$ of acetonitrile was subjected to chromatographic analysis under the same conditions previously described. These solutions were placed in injection vials where $1 \mu \mathrm{L}$ was injected into the chromatographic system of $1 \mu \mathrm{L}$ that was injected into the chromatographic system.

2.4. Characterization of Nanoemulsions. After the preparation, all formulations (produced in triplicate) were characterized by the following parameters: $\mathrm{pH}$, average particle size, polydispersity index, zeta potential, oil content, and morphology.

The $\mathrm{pH}$ was measured directly in the formulations with the aid of a calibrated potentiometer (DM-22, Digimed ${ }^{\circledR}$, Brazil). The dynamic light scattering technique using the Zetasizer equipment (Nano-ZS Zetasizer ${ }^{\circledR}$ model ZEN 3600, Malvern, United Kingdom) was used to determine the average particle size and polydispersity index (PDI). This technique measures the diffusion particles moving under Brownian motion and converts this measurement into size and size distribution of the formulations after dilution in ultrapure water previously filtered through a $0.45 \mu \mathrm{m}$ membrane (Sartorius RC 0.45 microns) [24].

The Doppler laser microelectrophoresis technique with Zetasizer equipment (Nano-ZS Zetasizer ${ }^{\circledR}$ model ZEN 3600, Malvern, United Kingdom) was used to evaluate the zeta potential, expressing the results in millivolts. An electric field is applied to a solution of molecules or a dispersion of particles, which will move at a velocity related to its zeta potential. This speed is measured by a laser interferometric technique (light scattering with phase analysis). In this regard, it is possible to determine the zeta potential through electrophoretic mobility calculation. The analyses were performed after dilution of the formulation in a $10 \mathrm{mM} \mathrm{NaCl}$ solution previously filtered through the $0.45 \mu \mathrm{m}$ membrane [24].

The oil content in the nanoemulsions was evaluated according to the methodology described above in Section 2.3.

According to Shi et al. [25], with modifications, the morphological analysis of the nanoemulsions containing $E$. globulus oil and blank nanoemulsions was evaluated using a transmission electron microscope at $80 \mathrm{kV}$ (TEM, JEOL, JEM 1200 Exll, Japan). Samples were diluted in water $(1: 10 \mathrm{v} / \mathrm{v})$ and dropped a drop on the grid. After 1 minute, the samples were dried with paper film and stained with uranyl acetate (2\%) and were maintained in a vacuum desiccator until the microscopic evaluations which were analyzed at different magnifications.
2.5. Stability Study. The stability of formulations was done according to Isaac et al. [26] immediately after they were prepared. The batches were produced and the physicochemical parameters described above (except morphology) were evaluated under different storage conditions: room temperature $\left(25^{\circ} \mathrm{C}\right)$, cooling $\left(4^{\circ} \mathrm{C}\right)$, and climate chamber $\left(40^{\circ} \mathrm{C}\right.$ and $65 \%$ humidity) at $0,7,15,30,60$, and 90 days. For analysis, we compared these data to zero time (after preparation).

2.6. Cytogenotoxicity In Vitro Evaluation. Peripheral blood mononuclear cells were used to evaluate cytogenotoxicity. The peripheral blood samples were obtained from samples with no identification from the Laboratório Escola de Análises Clínicas of the Centro Universitário Franciscano, Santa Maria, RS, Brazil, approved by the Ethics Committee for Research on Human Beings of Centro Universitário Franciscano (Protocol number CAAE: 31211214.4.0000.5306). The samples were obtained by venipuncture using heparin-like Vacutainer ${ }^{\circledR}$ tubes. The separation of mononuclear cells from peripheral blood (PBMC) by density gradient was performed (Histopaque ${ }^{\circledR}$-1077) by centrifugation, and the concentration of $2 \times 10^{5}$ cells was obtained by counting in a Neubauer chamber with trypan blue $0.4 \%$ staining.

From the E. globulus oil concentration in this formulation (5\%), three dilutions were standardized in pure RPMI $(0.1 \% / 0.2 \% / 0.3 \%)$ to be tested for genotoxicity in our nanoencapsulated essential oil, free oil, and blank formulation.

To verify the toxic effects of compound on cell viability and DNA damage, an experimental protocol was conducted similar to that described by Wilms et al. [27]. Three different groups were tested in cells: (a) nanoemulsion containing the E. globulus oil (NEO); (b) E. globulus free oil (FO); (c) blank nanoemulsion (BNE), composed of medium chain triglycerides replacing E. globulus oil in the formulation, being tested for the purpose of evaluating possible toxicity from the nanostructure composition. In addition, the controls used for the tests were a negative control $(\mathrm{C}-)$ consisting of culture medium containing the PBMC and a positive control $(\mathrm{C}+)$ containing culture medium and PBMC added $100 \mathrm{mM}$ hydrogen peroxide $\left(\mathrm{H}_{2} \mathrm{O}_{2}\right)$.

2.6.1. Cell Viability Assay. Cell viability was analyzed according to Mosmann [28]. The cytotoxic activity in peripheral blood mononuclear cells was evaluated by the colorimetric method whose principle is based on reduction of 3-(4,5-dimethyl thiazol-2-yl)-2,5-diphenyl tetrazolium bromide (MTT) in a dark purple MTT-formazan through mitochondrial succinate dehydrogenase tetrazolium enzyme activity. As the conversion occurs only in viable cells, the decreased absorbance of the test compared to negative controls indicates cell death. The experiment was performed in triplicate in a 96-well plate with samples and controls, negative and positive as described above. The plate was incubated at $37^{\circ} \mathrm{C}$ with $5 \% \mathrm{CO}_{2}$ during 72 hours. Then the sample absorbances were determined in a spectrophotometer at $570 \mathrm{~nm}$. The results were expressed as percentage of control. 
2.6.2. Lipid Peroxidation Measurement. The determination of lipid peroxidation was assessed by determining the thiobarbituric acid reactive species according to the method described by Ohkawa et al. [29] and modified by Carrera-Rotllan and Estrada-Garcia [30]. After 72 hours of incubation, an aliquot of each treatment was mixed with a reaction medium containing 2-thiobarbituric acid (TBA) $(0.8 \%)$ and incubated at $95^{\circ} \mathrm{C}$ for 1 hour. The absorbance was measured at a wavelength of $532 \mathrm{~nm}$ in a spectrophotometer and the results expressed as moles of malondialdehyde (MDA).

2.6.3. Protein Carbonylation Analysis. Oxidative damage of proteins was measured by determining the formation of carbonyl groups based on the reaction with dinitrophenylhydrazine as previously described by Levine et al. [31]. After homogenization, the carbonyl buffer samples $(120 \mathrm{~mm}$ $\mathrm{KCl}, 30 \mathrm{~mm} \mathrm{KH} \mathrm{PO}_{4}$ ) were centrifuged at $7000 \mathrm{~g}$ for 15 minutes at $4^{\circ} \mathrm{C}$ and lysed in $20 \%$ trichloroacetic acid (TCA). After lysing, the samples were centrifuged again at $14,000 \mathrm{~g}$ for 5 minutes. The pellet was resuspended in $100 \mu \mathrm{L}$ of $0.2 \mathrm{M} \mathrm{NaOH}$ and the samples were incubated for 1 hour at room temperature with $2 \mathrm{M} \mathrm{HCl}(1: 3)$ added to $10 \mathrm{mM}$ 2,4-dinitrophenylhydrazine (DNPH). After the incubation period, $100 \mu \mathrm{L}$ of trichloroacetic acid (TCA) $20 \%$ was added and samples were centrifuged at $14,000 \times \mathrm{g}$ for 3 minutes. The pellet was washed with $500 \mu \mathrm{L}$ of ethanol-ethylacetate. Samples were incubated for 30 minutes at $60^{\circ} \mathrm{C}$ and centrifuged again at $14,000 \mathrm{~g}$ for 3 minutes. The formation of carbonyl content was determined spectrophotometrically at $370 \mathrm{~nm}$.

2.6.4. Single Cell Gel Electrophoresis Assay: Comet Assay. The comet assay was performed according to Singh et al. [32] and modified by García et al. [33]. This test is highly sensitive and allows quantifying the levels of single-strand DNA breaks. On a glass slide covered previously with a $1.5 \%$ agarose layer, the mononuclear cells from peripheral blood were deposited and suspended in low-melting point agarose (Low Melting). The material was immersed in lysis solution $(89 \mathrm{~mL}$ lysing solution to $10 \mathrm{~mL}$ of dimethyl sulfoxide and $1 \mathrm{~mL}$ of Triton $\mathrm{X}$ 100) for the removal of membranes and cytoplasm. Subsequently, the slides were incubated in alkaline electrophoresis buffer $(300 \mathrm{mM} \mathrm{NaOH}$ and $1 \mathrm{mM}$ EDTA in distilled water) and subjected to electrophoresis for 30 minutes at $25 \mathrm{~V}$ and $300 \mathrm{~mA}$. Subsequently, the neutralization process was performed, fixation and staining by which genetic material can be analyzed.

Damage index calculation formula is DI $=\left(D_{1}+D_{2}+\right.$ $\left.D_{3}+D_{4}\right) / 100$.

2.6.5. Hemolysis Evaluation. According to Pequeno and Sotoblanco [34], the hemolytic activity of all treatments was measured in a spectrophotometer using a hemoglobin release assay. Summarily, defibrillator erythrocytes were washed three times with PBS $1 x$ and centrifuged for 15 minutes at $9,000 \mathrm{~g}$. After washings, a pool of erythrocytes was concentrated in a $10 \mathrm{~mL}$ tube. After this pool, $400 \mu \mathrm{L}$ of this procedure was removed and resuspended in $1 \mathrm{~mL}$ PBS $1 \mathrm{x}$. Subsequently, the cells were treated for 1 hour at $37^{\circ} \mathrm{C}$ and then centrifuged at $1,000 \mathrm{rpm}$ for 10 minutes. Aliquots of the supernatant were transferred to a microcentrifuge tube, where the release of hemoglobin was monitored using a PDReader microplate reader (Thermoplate ${ }^{\circledR}$, China), measuring the absorbance at $409 \mathrm{~nm}$. Percentage of hemolysis was calculated as $(\mathrm{AT}-\mathrm{AC}) /(\mathrm{AC}+-\mathrm{AC}-) \times 100$, where $\mathrm{AT}$ is the absorbance of the supernatant treated, $\mathrm{AC}-$ is the absorbance of the supernatant from control, cells treated with $\mathrm{PBS}$, and $\mathrm{AC}+$ is the absorbance of the treatment with hydrogen peroxide, which proves positive hemolytic activity.

2.7. Statistical Analysis. The characterization data and the study data "in vitro" were analyzed using Graphpad Prism 5.0 software followed by one-way ANOVA with Dunnett's post hoc test. Values of $p<0.05$ were considered statistically significant for both tests.

\section{Results and Discussion}

3.1. Characterization of the Essential Oil and Oil Content in the Nanoemulsions. The chemical components of E. globulus oil are shown in Table 1 . Its main components are 1,8cineole $(75.7 \%)$; p-cymene (7.5\%); alpha-pinene (7.3\%); and limonene (6.4\%). According to Vitti and Brito [35], the main component of E. globulus oil is the compound 1,8-cineole with an average concentration of $80 \%$. This composition corroborates our results of the oil composition (Table 1) by gas chromatography. Regarding oil content in nanoemulsions, the authors reported that the nanoemulsion preserved the percentage of the main oil compound, 1,8-cineole, for 90 days. This shows that the nanostructuring proposed in this study did not damage the oil composition.

3.2. Characterization of Nanoemulsion and Stability Study. After preparation, the nanoemulsions presented adequate nanometric properties as shown by Codevilla et al. [36] and Schaffazick et al. [37], with mean particle diameter and polydispersity index around $70 \mathrm{~nm}$ and 0.2 , respectively, a zeta potential of approximately $-9 \mathrm{mV}$, and acid $\mathrm{pH}$ (Table 2).

Scanning electron microscopy (SEM) and transmission (TEM) have long been used to obtain information about the shape and size of nanoparticles [37]. In this study, the morphological analysis of nanoemulsions containing E. globulus by transmission electron microscopy showed spherical particles (Figure 1(a)) and (Figure 1(b)) representing blank nanoemulsions, where the diameters were similar to those found in dynamic light scattering analysis, as demonstrated by Lee et al. [38], respecting the peculiarities of each technique.

According to Schaffazick et al. [37], the industrial advantage of nanoparticles dispersed in aqueous medium may present limitations, due to issues of poor physicochemical stability in storage for extended periods. Based on this, the authors observe that the formulation stored in a climate chamber after 7 days had a mean diameter of approximately $258 \mathrm{~nm}$; after 15 days, this formulation showed a polydispersity index of 0.3 . After being stored for 60 days, phase separation occurred, which made it impossible to read the parameters. It was then possible to verify instability in the formulation when stored at elevated temperatures $\left(40^{\circ} \mathrm{C}\right)$. It 
TABLE 1: Free E. globulus oil composition and oil composition in nanoemulsion.

\begin{tabular}{|c|c|c|c|c|c|}
\hline \multirow[t]{2}{*}{ Compound } & \multirow[t]{2}{*}{$\begin{array}{l}\text { Normalization } \\
\text { (\% free oil) }\end{array}$} & \multicolumn{4}{|c|}{$\begin{array}{l}\text { Normalization }{ }^{*} \pm \text { SD } \\
\text { (\% oil in nanoemulsion) }\end{array}$} \\
\hline & & After preparation & Day 30 & Day 60 & Day 90 \\
\hline alpha-Pinene & 7.39 & $5.55 \pm 0.13$ & $5.39 \pm 0.59$ & $5.28 \pm 0.84$ & $5.39 \pm 1.73$ \\
\hline beta-Pinene & 0.38 & $0.29 \pm 0.00$ & $0.30 \pm 0.02$ & $0.28 \pm 0.04$ & $0.29 \pm 0.04$ \\
\hline beta-Myrcene & 0.41 & $0.32 \pm 0.01$ & $0.32 \pm 0.02$ & $0.25 \pm 0.07$ & $0.34 \pm 0.05$ \\
\hline alpha-Phellandrene & 0.19 & $0.00 \pm 0.00$ & $0.00 \pm 0.00$ & $0.00 \pm 0.00$ & $0.03 \pm 0.05$ \\
\hline p-Cymene & 7.55 & $8.14 \pm 0.09$ & $8.33 \pm 0.27$ & $8.37 \pm 0.21$ & $7.89 \pm 0.41$ \\
\hline Limonene & 6.41 & $6.06 \pm 0.33$ & $5.94 \pm 0.04$ & $5.59 \pm 0.50$ & $3.96 \pm 0.38$ \\
\hline 1-8-Cineole & 75.78 & $77.30 \pm 0.34$ & $78.09 \pm 0.45$ & $78.54 \pm 1.23$ & $81.16 \pm 0.71$ \\
\hline gamma-Terpinene & 1.11 & $0.29 \pm 0.03$ & $0.20 \pm 0.15$ & $0.17 \pm 0.00$ & $0.24 \pm 0.32$ \\
\hline trans-Pinocarveol & 0.11 & $0.14 \pm 0.01$ & $0.19 \pm 0.01$ & $0.13 \pm 0.01$ & $0.10 \pm 0.09$ \\
\hline 4-Terpineol & 0.16 & $0.23 \pm 0.01$ & $0.22 \pm 0.00$ & $0.22 \pm 0.01$ & $0.18 \pm 0.02$ \\
\hline alpha-Terpineol & 0.41 & $0.51 \pm 0.04$ & $0.51 \pm 0.02$ & $0.53 \pm 0.04$ & $0.40 \pm 0.09$ \\
\hline Aromadendrene & 0.03 & $0.04 \pm 0.00$ & $0.04 \pm 0.00$ & $0.16 \pm 0.06$ & $0.03 \pm 0.01$ \\
\hline
\end{tabular}

${ }^{*}$ The analysis was performed in triplicate $(n=3)$.

TABLE 2: Stability of the nanoemulsions containing Eucalyptus globulus oil in 0-90-day periods.

\begin{tabular}{|c|c|c|c|c|c|}
\hline Time & Conditions & $\begin{array}{c}\text { Size } \\
(\mathrm{nm}) \pm \mathrm{SD}\end{array}$ & $\mathrm{PDI} \pm \mathrm{SD}$ & $\begin{array}{c}\text { Zeta potential } \\
(\mathrm{mV}) \pm \mathrm{SD}\end{array}$ & $\mathrm{pH} \pm \mathrm{SD}$ \\
\hline After preparation & - & $75.57 \pm 14.73$ & $0.22 \pm 0.04$ & $-9.42 \pm 1.15$ & $4.68 \pm 0.05$ \\
\hline \multirow{3}{*}{7 days } & RT & $75.74 \pm 5.85$ & $0.25 \pm 0.03$ & $-15.83 \pm 1.62^{* *}$ & $4.26 \pm 0.08^{* *}$ \\
\hline & $\mathrm{RE}$ & $73.81 \pm 8.35$ & $0.23 \pm 0.03$ & $-7.97 \pm 2.10$ & $4.55 \pm 0.06^{*}$ \\
\hline & $\mathrm{CC}$ & $257.93 \pm 66.86$ & $0.26 \pm 0.08$ & $-10.50 \pm 2.24$ & $3.25 \pm 0.04^{* * *}$ \\
\hline \multirow{3}{*}{15 days } & RT & $74.23 \pm 6.07$ & $0.24 \pm 0.03$ & $-19.5 \pm 2.02^{* * *}$ & $4.93 \pm 0.08^{*}$ \\
\hline & $\mathrm{RE}$ & $73.71 \pm 14.80$ & $0.26 \pm 0.05$ & $-9.26 \pm 0.71$ & $4,33 \pm 0.04^{* * *}$ \\
\hline & $\mathrm{CC}$ & $248.93 \pm 97.94$ & $0.35 \pm 0.12$ & $-17.53 \pm 4.09^{* *}$ & $4.12 \pm 0.05^{* * *}$ \\
\hline \multirow{3}{*}{30 days } & RT & $76.92 \pm 0.45$ & $0.24 \pm 0.07$ & $-14.03 \pm 3.30$ & $3.66 \pm 0.13^{* * *}$ \\
\hline & $\mathrm{RE}$ & $80.03 \pm 17.55$ & $0.32 \pm 0.10$ & $-11.63 \pm 3.69$ & $4.24 \pm 0.14^{* * *}$ \\
\hline & $\mathrm{CC}$ & $488.93 \pm 147.76^{* *}$ & $0.56 \pm 0.09^{* *}$ & $-22.27 \pm 2.73^{* *}$ & $2.91 \pm 0.07^{* * *}$ \\
\hline \multirow{3}{*}{60 days } & RT & $83.37 \pm 3.87$ & $0.18 \pm 0.04$ & $-12.60 \pm 0.29$ & $3.14 \pm 0.12^{* * *}$ \\
\hline & $\mathrm{RE}$ & $76.04 \pm 6.03$ & $0.25 \pm 0.03$ & $-11.57 \pm 4.15$ & $4.08 \pm 0.05^{* * *}$ \\
\hline & $\mathrm{CC}$ & $486.20 \pm 92.48^{* *}$ & $0.53 \pm 0.09^{*}$ & $-23.37 \pm 2.17^{* * *}$ & $2.72 \pm 0.07^{* * *}$ \\
\hline \multirow{3}{*}{90 days } & RT & $152.47 \pm 38.81^{* *}$ & $0.07 \pm 0.06^{*}$ & $-18.87 \pm 0.31^{* * *}$ & $2.99 \pm 0.11^{* * *}$ \\
\hline & $\mathrm{RE}$ & $74.97 \pm 8.36$ & $0.24 \pm 0.02$ & $-10.40 \pm 2.61$ & $4.21 \pm 0.02^{* * *}$ \\
\hline & $\mathrm{CC}$ & - & - & - & - \\
\hline
\end{tabular}

Storage conditions: RT: room temperature $\left(25^{\circ} \mathrm{C}\right)$; RE: refrigeration $\left(4^{\circ} \mathrm{C}\right)$; CC: climatic chamber $\left(40^{\circ} \mathrm{C}\right.$ and $65 \%$ humidity). The analyses were carried out by variance (ANOVA) of one way, followed by Dunnett's test. Values of $p<0.05$ were considered statistically significant. ${ }^{*} p<0.05,{ }^{* *} p<0.01$, and ${ }^{* * *} p<$ 0.001 .

is suggested that a possible reason for instability of the $E$. globulus in this condition has been the formulation of an oxidative process caused by the high temperature at which it is stored.

In the formulation stored at room temperature $\left(25^{\circ} \mathrm{C}\right)$ within 90 days, an increased size and zeta potential to about $152.47 \mathrm{~nm}$ and $-18.87 \mathrm{mV}$, respectively, were observed, and the polydispersity index was 0.07 , and the $\mathrm{pH}$ was close to 3 .

The formulation kept under refrigeration retained its nanometric characteristics 90 days after preparation, while keeping its average particle size of approximately $75 \mathrm{~nm}$, polydispersion index of 0.2 , the zeta potential of $-10.4 \mathrm{mV}$, and acidic $\mathrm{pH}$ (around 4.2). This study showed evidence that cooling is the best form of storage for nanoemulsions.

3.3. Evaluation of Cytogenotoxic Effects. As described by Maluf and Riegel [39], peripheral blood mononuclear cells (PBMC) have been used for years as biological markers of cytogenotoxic effects. Because they are abundant in the bloodstream, these cells can be exposed to any mutagen and 


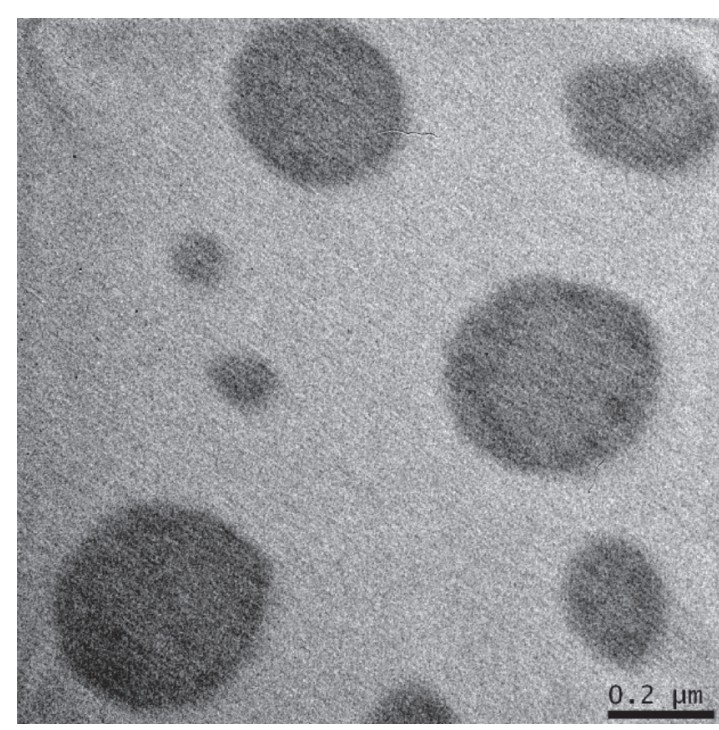

(a)

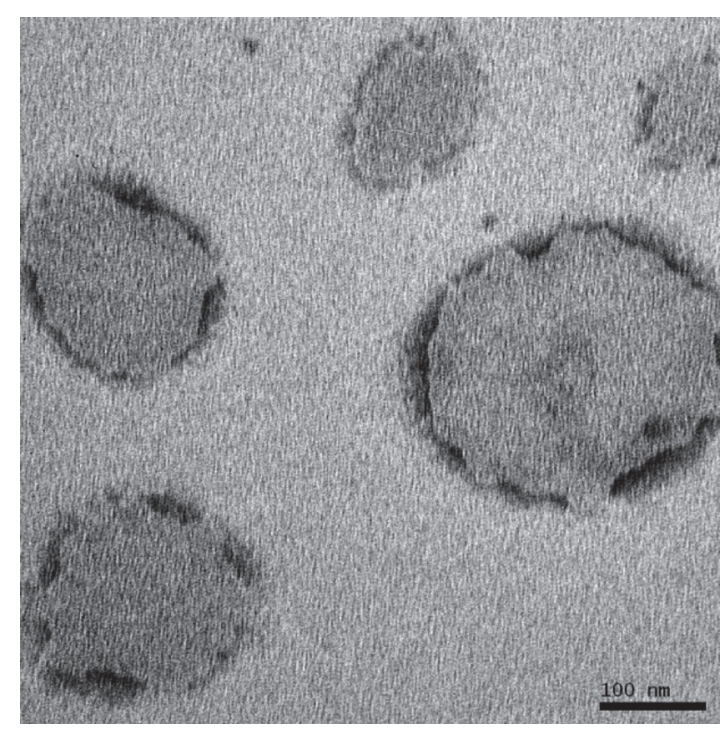

(b)

FIGURE 1: Transmission electron microscopy images of nanoemulsion of Eucalyptus globulus oil (a) and blank nanoemulsion (b) [bar $=200$ $\mathrm{nm}(100,000 \mathrm{x})]$.

have the ability to demonstrate recent damage. As the PBMC grow, they provide a very promising in vitro model for various studies, and the usefulness of this cell line is mentioned in cytogenotoxicity studies.

3.3.1. Cell Viability Assay. The human structure suffers continuous action of reactive oxygen species (ROS) and reactive nitrogen species (RNS) produced in inflammatory processes arising from biological or nutritional changes. The main ROS are the superoxide anion that is catalyzed by catalase and/or GPx to hydrogen peroxide and plays an important role in oxidative stress, having the ability to cross cell membranes and produce hydroxyl radicals [40]. Thus it is highly toxic to the cells [41].

In this study, hydrogen peroxide $\left(\mathrm{H}_{2} \mathrm{O}_{2}\right)$ was used as a positive control indicating cell death due to its high performance as a reactive species; therefore, values less than the positive control are not viable and cell values greater than the negative control indicate cell proliferation.

Figure 2 shows the results of the MTT assay on PBMC after 72 hours of treatment. This analysis demonstrated that none of the test groups compared to negative control caused cell death. These results showed that neither the free E. globulus oil nor E. globulus nanoemulsion and blank formulation caused damaged to the cell mitochondria, suggesting that they do not present cytotoxic effects.

3.3.2. Lipid Peroxidation Measurement. Lipid peroxidation in biological processes can occur in several ways including nonenzymatic means, where the mechanism involves reactive oxygen species, free radicals, and other metals. All oxidative processes trigger changes in physical and chemical properties of the membrane, altering the fluidity and permeability by spreading the intracellular fluid and risk of rupture of cell membranes and organelles, resulting in cell death [42]. The

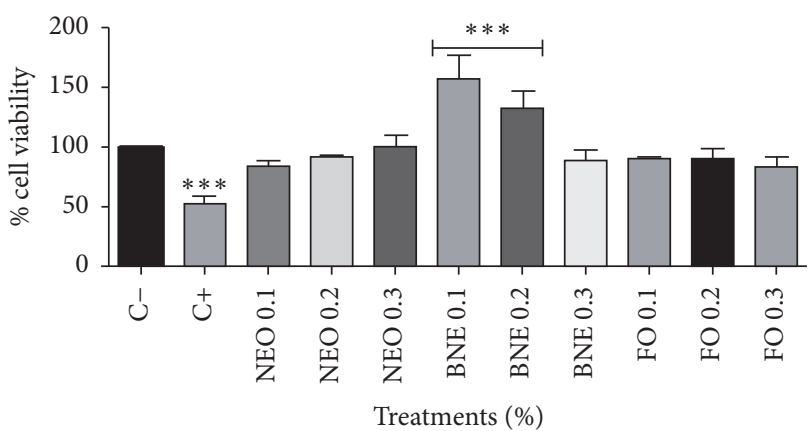

Figure 2: MTT assay after $72 \mathrm{~h}$ of incubation. Results expressed as percentage of the negative control (100\%). Negative control (C-): cells in culture medium; positive control $(\mathrm{C}+)$ : cells with $\mathrm{H}_{2} \mathrm{O}_{2}$. Data are expressed as mean \pm standard deviation (SD). Analyses were performed by variance (ANOVA) of one way, followed by Dunnett's test. Values with $p<0.05$ were considered statistically significant. ${ }^{*} p<0.05,{ }^{* *} p<0.01$, and ${ }^{* * *} p<0.001$.

product of this lipid peroxidation is malondialdehyde which is a reactive aldehyde used widely as a biomarker [43]. In Figure 3, we can observe the levels of TBARS in PBMC after 72 hours of treatment with NEO, BNE, and FO at three concentrations. The results showed that the free $E$. globulus oil (FO) demonstrated a dose-dependent toxicity profile and the production of thiobarbituric acid reactive species increased as the oil concentration increased; we can highlight the concentration of $0.3 \%$ which was equal to the negative control.

When PBMC came into contact with E. globulus nanoemulsions (NEO), the profile observed was the contrary of that in the graph shown above, because when the concentration of NEO increased, the cells were protected by oil nanoencapsulation. And the BNE did not induce cell oxidation, proving the nontoxicity of the formulation proposed in this paper. 


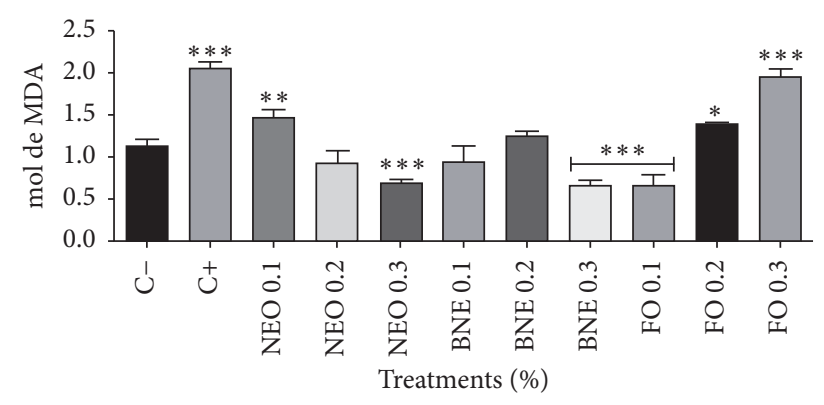

FIGURE 3: TBARS assay with 72 hours of incubation. Results expressed as percentage of the negative control (100\%). Negative control $(\mathrm{C}-)$ : cells in culture medium; positive control $(\mathrm{C}+)$ : cells with $\mathrm{H}_{2} \mathrm{O}_{2}$. Data are expressed as mean \pm standard deviation (SD). Analyses were performed by variance (ANOVA) of one way, followed by Dunnett's test. Values with $p<0.05$ were considered statistically significant. ${ }^{*} p<0.05,{ }^{* *} p<0.01$, and ${ }^{* * *} p<0.001$.

3.3.3. Protein Carbonylation Analysis. Carbonylation can alter the conformation and activity of proteins and trigger the formation of protein aggregates [44]. According to the descriptions by Nyström [45], the task of identifying the factors that trigger carbonylation has been difficult, but there are many possibilities including the reduction of the antioxidant defense process and an increase in the generation of reactive oxygen species (ROS) reducing the ability to remove oxidized proteins or increasing the sensitivity of proteins to oxidative attack.

Figure 4 shows the evaluation of protein carbonylation induction after 72 hours of exposure to the treatment conditions. The results show that free E. globulus oil, nanoemulsion from E. globulus, and blank nanoemulsion did not cause protein damage to the cells compared to negative control.

3.3.4. Single Cell Gel Electrophoresis Assay: Comet Assay. As described by Brianezi [46], the study of comets is the degree of DNA fragmentation and its migration by microelectrophoresis. Currently, this method is a widely used genotoxicity test of industrial, pharmaceutical, and agrochemical products for damage and DNA repair in individual cells. It is relatively easy to implement, is fast, is of a lower cost, and is safe.

Each slide was analyzed under a light microscope and the cells were classified according to the image, based on four classes of damage proposed by García and coworkers [33] and illustrated by Fronza and collaborators [47], ranging from 0 (no damage) to 4 (maximum injury), but also including cellular apoptosis rating.

Based on Figure 5, we compare the results obtained with the negative control DNA damage; we can say that the nanoemulsion containing E. globulus oil, free oil, and blank nanoemulsion did not cause breakage or damage to the DNA.

3.3.5. Hemolysis Evaluation. Based on Figure 6, we found that the nanoemulsion at a concentration of $0.1 \%$ oil had a better protective effect on the cells by preventing cell destruction, a process called hemolysis. Likewise, the behavior of the BNE

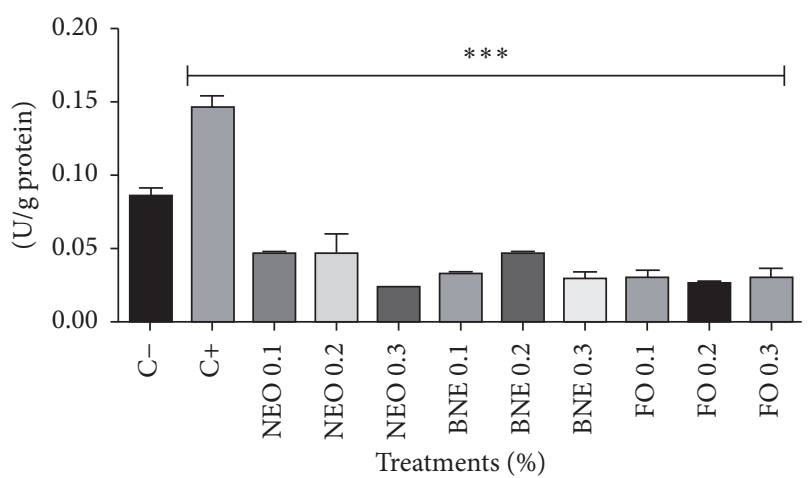

FIGURE 4: Protein carbonylation assay with 72 hours of incubation. Results expressed as percentage of the negative control (100\%). Negative control (C-): cells in culture medium; positive control $(\mathrm{C}+)$ : cells with $\mathrm{H}_{2} \mathrm{O}_{2}$. Data are expressed as mean \pm standard deviation (SD). Analyses were performed by variance (ANOVA) of one way, followed by Dunnett's test. Values with $p<0.05$ were considered statistically significant. ${ }^{*} p<0.05,{ }^{* *} p<0.01$, and ${ }^{* * *} p<0.001$

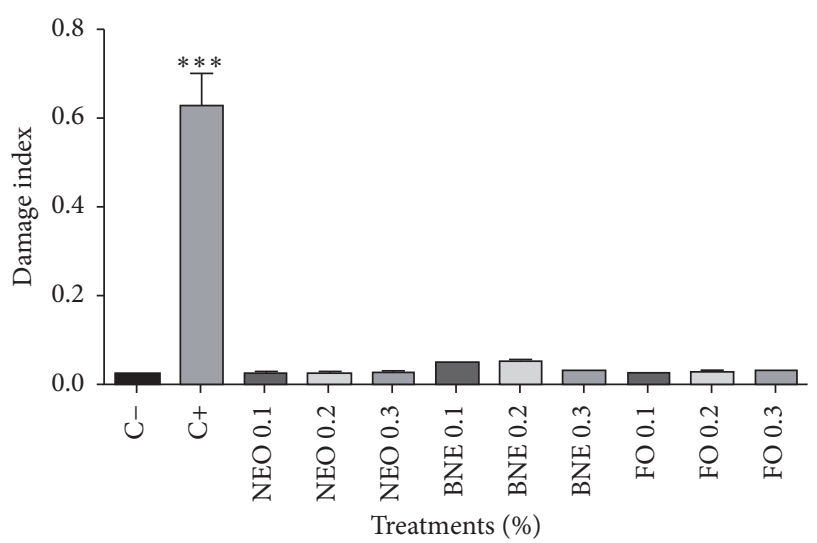

FIgURE 5: Comet assay with 72 hours of incubation. Results expressed as percentage of the negative control (100\%). Negative control $(\mathrm{C}-)$ : cells in culture medium; positive control $(\mathrm{C}+)$ : cells with $\mathrm{H}_{2} \mathrm{O}_{2}$. Data are expressed as mean \pm standard deviation (SD). Analyses were performed by variance (ANOVA) of one way, followed by Dunnett's test. Values with $p<0.05$ were considered statistically significant. ${ }^{*} p<0.05,{ }^{* *} p<0.01$, and ${ }^{* * *} p<0.001$.

and the FO (both $0.1 \%$ ) did not cause cellular destruction at the lowest concentration showing that the formulation and oil are nontoxic in this case.

Already at a concentration of $0.2 \%$, a different situation was evidenced, in which the NEO and FO caused hemolysis. It is assumed that this may have been caused by the action of some component present in the E. globulus oil, as compared to the BNE and the FO or NEO. We found that the formulation without oil (BNE) at this concentration did not induce cell lysis. According to Bruxel et al. [48], the use of nonionic surfactants from the group of poloxamer and polyoxyethylene sorbitans (Tweens) has shown a favorable in association with phospholipids, as they lead to the formation of compact mixed films, conferring greater stability to the 


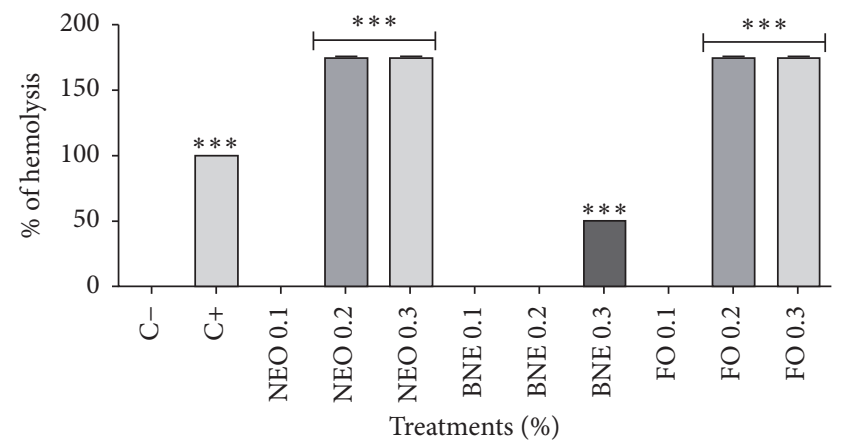

Figure 6: Hemolysis assay after 1 hour of incubation. Results expressed as percentage of the negative control (100\%). Negative control (C-): cells in culture medium; positive control $(\mathrm{C}+)$ : cells with $\mathrm{H}_{2} \mathrm{O}_{2}$. Data are expressed as mean \pm standard deviation (SD). Analyses were performed by variance (ANOVA) of one way, followed by Dunnett's test. Values with $p<0.05$ were considered statistically significant. ${ }^{*} p<0.05,{ }^{* *} p<0.01$, and ${ }^{* * *} p<0.001$.

formulation. However, hemolytic reactions and changes in droplet diameter of nanoemulsions stabilized with Tween 80 can limit their use alone, which was verified at the concentration of $0.3 \%$ also for the NEB.

We conclude that the safety of the formulation is minimized when the oil is found at higher concentrations causing toxicity against red blood cells triggering hemolytic action. This behavior can be attributed to any compound present in the oil, as demonstrated in the study by Mendanha et al. [49], which showed hemolytic action in erythrocytes when exposed to terpene 1-8 cineol at high concentrations, corroborating our results since this is the main component of E. globulus oil. It is also assumed that this may be due to limitations of the technique, such as the short analysis time while this method is being carried out, improperly performed blood collection, or a prior hemolytic condition of the patient. Based on the above discussion, further studies are suggested to investigate the real cause of the hemolytic process triggered in the presence of nanostructures.

\section{Conclusion}

The present study performed a successful nanoencapsulation of essential oil of Eucalyptus (E. globulus) at a concentration of $5 \%$ through nanoemulsions, which, after evaluation, showed adequate nanometric properties according to the literature.

It is noteworthy that, for the methodology of nanoemulsion, no organic solvent was used or it was employed using a rotary evaporator stage. Furthermore, there was temperature control throughout the process, thus avoiding the volatilization of oil or its structural components, minimizing the chances of an ineffective encapsulation process.

We also demonstrated a prolonged durability profile when the nanoemulsions were stored under refrigeration $\left(4^{\circ} \mathrm{C}\right)$, storage being possible for 90 days without any loss of stability. Nanoemulsions produced showed appropriate morphology and preserved the same amounts of the major component of the essential oil in the nanostructure within 90 days.
Through the study of cytogenotoxicity in PBMC, we can say that E. globulus nanoemulsion did not cause cell death; it showed a protective effect on cells when exposed to species of lipid peroxidation; it also did not provide protein carbonyls or cause damage to the DNA of the cells tested; however, it should be noted that the E. globulus nanoemulsion at high concentrations may trigger lysis of erythrocytes. Based on these results, we can say that $0.1 \%$ is the safest concentration for the use of Eucalyptus globulus nanoemulsions in human cells.

\section{Conflicts of Interest}

The authors declare that there are no conflicts of interest regarding the publication of this paper.

\section{Acknowledgments}

S. N. Godoi acknowledges the National Council of Technological and Scientific Development (CNPq) for financial support for this research and Centro Universitário Franciscano for enabling this study to be performed. The authors acknowledge the financial support of CNPq, Brazil, and CAPES, Brazil.

\section{References}

[1] J. C. De Araujo, E. De O. Lima, B. S. O. de Ceballos, K. R. de L. Freire, E. L. de Souza, and L. Santos Filho, "Ação antimicrobiana de óleos essenciais sobre microrganismos potencialmente causadores de infecções oportunistas," Revista de Patologia Tropical, vol. 33, no. 1, 2007.

[2] H. Nasri and H. Shirzad, "Toxicity and safety of medicinal plants," Journal of Herbmed Pharmacology, vol. 2, no. 2, pp. 2122, 2013.

[3] D. Hernández, J. Orozco, R. Serrano et al., “Temporal variation of chemical composition and antimicrobial activity of the essential oil of cordia curassavica (Jacq.) roemer and schultes: boraginaceae," Boletin Latinoamericano y del Caribe de Plantas Medicinales y Aromaticas, vol. 13, no. 1, pp. 100-108, 2014.

[4] C. A. S. F. Miranda, M. G. Cardoso, L. R. Batista, L. M. A. Rodrigues, and A. C. S. Figueiredo, "Óleos essenciais de folhas de diversas espécies: propriedades antioxidantes e antibacterianas no crescimento espécies patogênicas," Revista Ciência Agronômica, vol. 47, no. 1, pp. 213-220, 2016.

[5] A. R. Bilia, C. Guccione, B. Isacchi, C. Righeschi, F. Firenzuoli, and M. C. Bergonzi, "Essential oils loaded in nanosystems: a developing strategy for a successful therapeutic approach," Evidence-Based Complementary and Alternative Medicine, vol. 2014, Article ID 651593, 14 pages, 2014.

[6] H. R. Bizzo, A. M. Hovell, and C. M. Rezende, "Óleos essenciais no Brasil: aspectos gerais, desenvolvimento e perspectivas," Química Nova, vol. 32, no. 3, pp. 588-594, 2009.

[7] J. Hafsa, M. a. Smach, M. R. Ben Khedher et al., "Physical, antioxidant and antimicrobial properties of chitosan films containing Eucalyptus globulus essential oil," LWT_Food Science and Technology, vol. 68, pp. 356-364, 2016.

[8] M. E. N. Rocha and C. L. Santos, "O uso comercial e popular do Eucalipto Eucalyptus globulus Labill - Myrtaceae," Saúde \& Ambiente em Revista, vol. 2, no. 2, pp. 23-34, 2007. 
[9] A. Estanislau, F. Barros, A. Peña, S. Santos, P. H. Ferri, and J. Paula, "Composição química e atividade antibacteriana dos óleos essenciais de cinco espécies de Eucalyptus cuItivadas em Goiás," Revista Brasileira de Farmacognosia, vol. 11, no. 2, pp. 95-100, 2001.

[10] S. K. Shahi and M. P. Shahi, "Broad spectrum herbal therapy against superficial fungal infections," Skin Pharmacology and Applied Skin Physiology, vol. 13, no. 1, pp. 60-64, 2000.

[11] J. Weiss, S. Gaysinsky, M. Davidson, and J. McClements, "Nanostructured Encapsulation Systems: Food Antimicrobials," Global Issues in Food Science and Technology, pp. 425-479, 2009.

[12] S. A. Saraf, "Applications of novel drug delivery system for herbal formulations," Fitoterapia, vol. 81, no. 7, pp. 680-689, 2010.

[13] K. C. S. Galvão, "Desenvolvimento de nanoemulsões para uso em alimentos e uso tópico," in Tese - Ciências da Engenharia de Alimentos, Universidade de São Paulo, 2015.

[14] A. Blanco-Padilla, K. M. Soto, M. Hernández Iturriaga, and S. Mendoza, "Food antimicrobials nanocarriers," Scientific World Journal, vol. 2014, Article ID 837215, 2014.

[15] C. M. Pey, A. Maestro, I. Solé, C. González, C. Solans, and J. M. Gutiérrez, "Optimization of nano-emulsions prepared by lowenergy emulsification methods at constant temperature using a factorial design study," Colloids and Surfaces A: Physicochemical and Engineering Aspects, vol. 288, no. 1-3, pp. 144-150, 2006.

[16] L. R. Kourniatis, L. S. Spinelli, C. R. E. Mansur, and G. González, "Orange oil/water nanoemulsions prepared by high pressure homogenizer," Quimica Nova, vol. 33, no. 2, pp. 295-300, 2010.

[17] W. Lu, D. Huang, C. Wang et al., "Preparation, characterization, and antimicrobial activity of nanoemulsions incorporating citral essential oil," Journal of Food and Drug Analysis, vol. 30, pp. 1-8, 2017.

[18] M. R. F. Gomes, R. S. Schuh, A. L. B. Jacques et al., "Citotoxic activity evaluation of essential oils and nanoemulsions of Drimys angustifolia and D. brasiliensis on human glioblastoma (U-138 MG) and human bladder carcinoma (T24) cell lines in vitro," Brazilian Journal of Pharmacognosy, vol. 23, no. 2, pp. 259-267, 2013.

[19] J. L. Duarte, J. R. R. Amado, A. E. M. F. M. Oliveira et al., "Evaluation of larvicidal activity of a nanoemulsion of rosmarinus officinalis essential oil," Brazilian Journal of Pharmacognosy, vol. 25, no. 2, pp. 189-192, 2015.

[20] S. Sugumar, S. K. Clarke, M. J. Nirmala, B. K. Tyagi, A. Mukherjee, and N. Chandrasekaran, "Nanoemulsion of eucalyptus oil and its larvicidal activity against Culex quinquefasciatus," Bulletin of Entomological Research, vol. 104, no. 3, pp. 393-402, 2014.

[21] M. Pant, S. Dubey, P. K. Patanjali, S. N. Naik, and S. Sharma, "Insecticidal activity of eucalyptus oil nanoemulsion with karanja and jatropha aqueous filtrates," International Biodeterioration and Biodegradation, vol. 91, pp. 119-127, 2014.

[22] M. M. Morales, "Métodos Alternativos à Utilização de animais em Pesquisa Científica: mito ou verdade?" Ciência e Cultura, vol. 60, no. 2, 2008.

[23] J. Amini, V. Farhang, T. Javadi, and J. Nazemi, "Antifungal effect of plant essential oils on controlling Phytophthora species," Plant Pathology Journal, vol. 32, no. 1, pp. 16-24, 2016.

[24] Manual do equipamento - Zetasizer Nano ZS, "Zetasizer Nano now measures across extended temperature range to $120^{\circ} \mathrm{C}$," Pigment \& Resin Technology, vol. 34, no. 4, 2005, http://www .malvern.com/br/products/product-range/zetasizer-range/ zetasizer-nano-range/zetasizer-nano-zs/default.aspx, 2016.
[25] F. Shi, J.-H. Zhao, Y. Liu, Z. Wang, Y.-T. Zhang, and N.-P. Feng, "Preparation and characterization of solid lipid nanoparticles loaded with frankincense and myrrh oil," International Journal of Nanomedicine, vol. 7, pp. 2033-2043, 2012.

[26] V. L. B. Isaac, L. C. Cefali, B. G. Chiari, C. C. L. G. Oliveira, H. R. N. Salgado, and M. A. Corrêa, "Protocolo para ensaios físicoquímicos de estabilidade de fitocosméticos," Revista de Ciências Farmacêuticas Básica e Aplicada, vol. 29, no. 1, pp. 81-96, 2008.

[27] L. C. Wilms, P. C. H. Hollman, A. W. Boots, and J. C. S. Kleinjans, "Protection by quercetin and quercetin-rich fruit juice against induction of oxidative DNA damage and formation of BPDE-DNA adducts in human lymphocytes," Mutation Research - Genetic Toxicology and Environmental Mutagenesis, vol. 582, no. 1-2, pp. 155-162, 2005.

[28] T. Mosmann, "Rapid colorimetric assay for cellular growth and survival: application to proliferation and cytotoxicity assays," Journal of Immunological Methods, vol. 65, no. 1-2, pp. 55-63, 1983.

[29] H. Ohkawa, N. Ohishi, and K. Yagi, "Assay for lipid peroxides in animal tissues by thiobarbituric acid reaction," Analytical Biochemistry, vol. 95, no. 2, pp. 351-358, 1979.

[30] J. Carrera-Rotllan and L. Estrada-Garcia, "Age-dependent changes and interrelations of number of cells and biochemical parameters (glucose, triglycerides, TBARS, calcium, phosphorus) in cultured human vein endothelial cells," Mechanisms of Ageing and Development, vol. 103, no. 1, pp. 13-26, 1998.

[31] R. L. Levine, D. Garland, C. N. Oliver et al., "Determination of carbonyl content in oxidatively modified proteins," Methods in Enzymology, vol. 186, pp. 464-478, 1990.

[32] N. P. Singh, M. T. McCoy, R. R. Tice, and E. L. Schneider, "A simple technique for quantitation of low levels of DNA damage in individual cells," Experimental Cell Research, vol. 175, no. 1, pp. 184-191, 1988.

[33] O. García, T. Mandina, A. I. Lamadrid et al., "Sensitivity and variability of visual scoring in the comet assay: results of an inter-laboratory scoring exercise with the use of silver staining," Mutation Research, vol. 556, no. 1-2, pp. 25-34, 2004.

[34] N. F. Pequeno and B. Soto-blanco, "Toxicidade in vitro de plantas tóxicas: avaliação do teste de ação hemolítica," Acta Scientiae Veterinariae, vol. 34, no. 1, pp. 45-48, 2006.

[35] A. M. S. Vitti and J. O. Brito, "Óleo essencial de eucalipto," Documentos Florestais - USP, vol. 17, pp. 1-26, 2003.

[36] C. F. Codevilla, M. T. Bazana, C. B. Silva, J. S. Barin, and C. R. Menezes, "Nanoestruturas contendo compostos bioativos extraídos de plantas," Revista do Centro de Ciências Naturais e Exatas - UFSM, vol. 37, p. 142, 2015, Edição Especial-Nano e Microencapsulação de compostos bioativos e probióticos em alimentos.

[37] S. R. Schaffazick, S. S. Guterres, L. de Lucca Freitas, and A. R. Pohlmann, "Caracterização e estabilidade físico-química de sistemas poliméricos nanoparticulados para administração de fármacos," Química Nova, vol. 26, no. 5, pp. 726-737, 2003.

[38] M. Lee, S. Lim, and C. Kim, "Preparation, characterization and in vitro cytotoxicity of paclitaxel-loaded sterically stabilized solid lipid nanoparticles," Biomaterials, vol. 28, no. 12, pp. 21372146, 2007.

[39] S. W. Maluf and M. Riegel, Citogenética Humana, Artmed, Porto Alegre, 2011.

[40] A. L. B. S. Barreiros, J. M. David, and J. P. David, "Oxidative stress: relations between the formation of reactive species and the organism's defense," Quimica Nova, vol. 29, no. 1, pp. 113123, 2006. 
[41] A. Ferreira and L. Matsubara, "Radicais livres: conceitos, doenças relacionadas, sistema de defesa e estresse oxidativo," Revista da Associação Médica Brasileira, vol. 43, no. 1, pp. 6168, 1997.

[42] S. M. Vasconcelos, M. O. Goulart, J. B. Moura, V. Manfredini, M. d. Benfato, and L. T. Kubota, "Espécies reativas de oxigênio e de nitrogênio, antioxidantes e marcadores de dano oxidativo em sangue humano: principais métodos analíticos para sua determinação," Química Nova, vol. 30, no. 5, pp. 1323-1338, 2007.

[43] J. Pilz, I. Meineke, and C. H. Gleiter, "Measurement of free and bound malondialdehyde in plasma by high-performance liquid chromatography as the 2,4-dinitrophenylhydrazine derivative," Journal of Chromatography B: Biomedical Sciences and Applications, vol. 742, no. 2, pp. 315-325, 2000.

[44] G. Aldini, I. Dalle-Donne, R. Colombo, R. M. Facino, A. Milzani, and M. Carini, "Lipoxidation-derived reactive carbonyl species as potential drug targets in preventing protein carbonylation and related cellular dysfunction," ChemMedChem, vol. 1, no. 10, pp. 1045-1058, 2006.

[45] T. Nyström, "Role of oxidative carbonylation in protein quality control and senescence," EMBO Journal, vol. 24, no. 7, pp. 13111317, 2005.

[46] G. Brianezi, J. L. Camargo, and H. A. Miot, "Desenvolvimento e validação de técnica quantitativa de análise de imagem para avaliação do teste do cometa corado pela prata," Jornal Brasileiro de Patologia e Medicina Laboratorial, vol. 45, no. 4, 2009.

[47] A. B. Fronza, D. C. M. Barreto, T. M. Tochetto, I. B. M. da Cruz, and A. F. da Silveira, "Association between auditory pathway efferent functions and genotoxicity in young adults," Brazilian Journal of Otorhinolaryngology, vol. 77, no. 1, pp. 107-114, 2011.

[48] F. Bruxel, M. Laux, L. B. Wild, M. Fraga, L. S. Koester, and H. F. Teixeira, "Nanoemulsões como sistemas de liberação parenteral de fármacos," Química Nova, vol. 35, no. 9, pp. 1827-1840, 2012.

[49] S. A. Mendanha, S. S. Moura, J. L. V. Anjos, M. C. Valadares, and A. Alonso, "Toxicity of terpenes on fibroblast cells compared to their hemolytic potential and increase in erythrocyte membrane fluidity," Toxicology In Vitro, vol. 27, no. 1, pp. 323-329, 2013. 

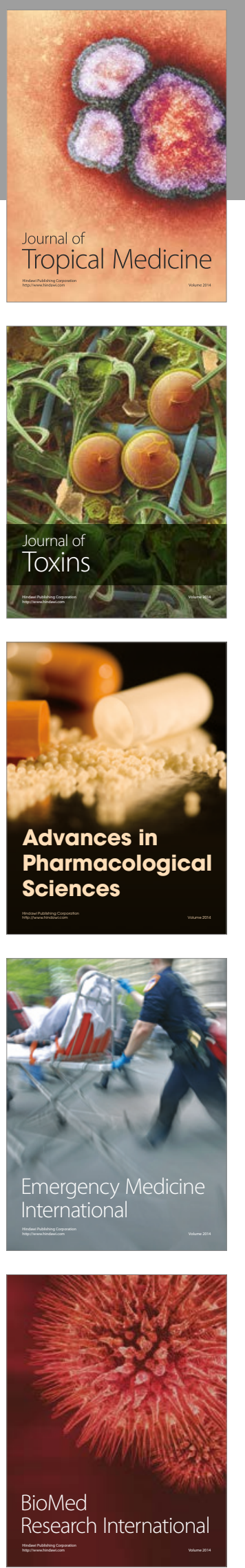
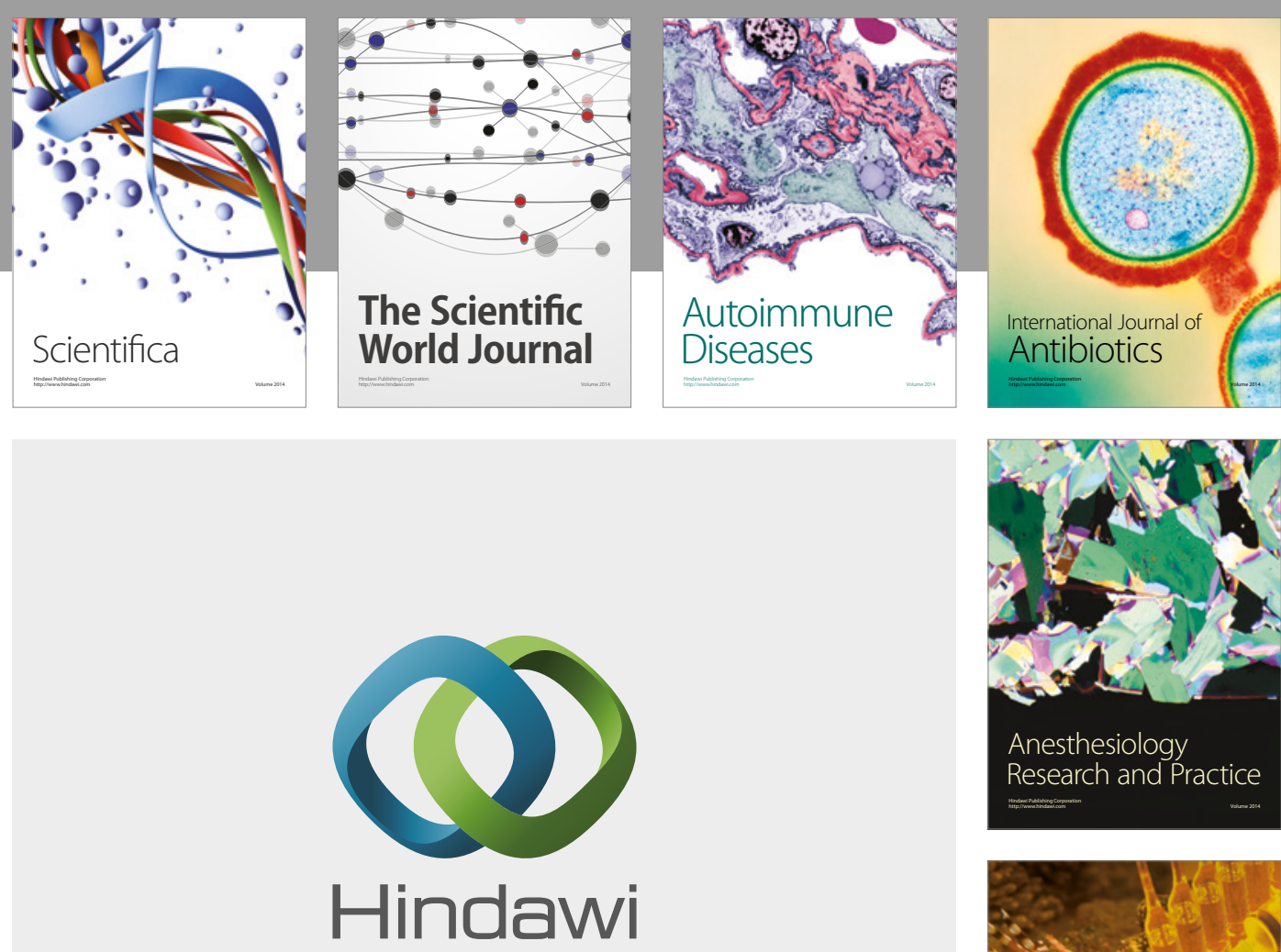

Submit your manuscripts at

https://www.hindawi.com
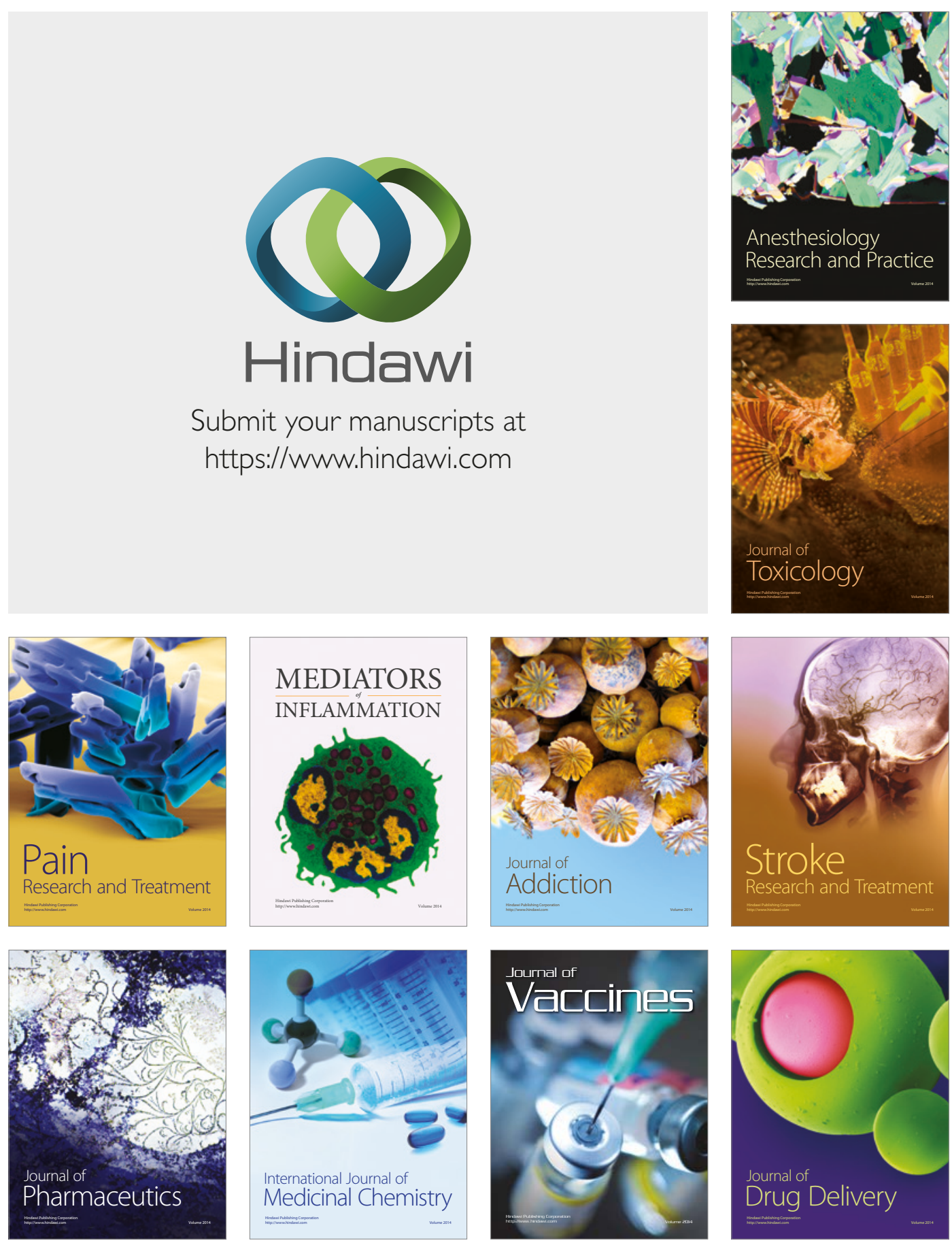